\title{
Redox Behaviour of a Tris(pyrazolyl)methanesulfonate Vanadium Complex, a Preliminary Study
}

\author{
T.F.S. Silva, ${ }^{a, b, c, *}$ L.M.D.R.S. Martins, ${ }^{a, b}$ A.J.L. Pombeiro ${ }^{a}$ \\ ${ }^{a}$ Departamento de Engenharia Química, ISEL, R. Conselheiro Emídio Navarro, \\ 1950-062 Lisboa, Portugal \\ ${ }^{b}$ Centro de Química Estrutural, Complexo I, IST, Av. Rovisco Pais, 1049-001 Lisboa, Portugal \\ ${ }^{c}$ Área Cientifica de Física, ISEL, R. Conselheiro Emídio Navarro, 1950-062 Lisboa, Portugal
}

Received 14 November 2005; accepted 23 November 2005

\begin{abstract}
The electrochemical behaviour of the new vanadium(IV) complex $\left[\mathrm{VCl}_{3}\left(\mathrm{SO}_{3} \mathrm{Cpz}_{3}\right)\right]$ (pz $=$ pyrazolyl), obtained by reaction of $\mathrm{VCl}_{3}$ with $\mathrm{Li}\left[\mathrm{SO}_{3} \mathrm{Cpz}_{3}\right]$, investigated by cyclic voltammetry and controlled potential electrolysis is reported and compared with those of hydrotris(pyrazolyl)borate vanadium(IV) complexes.
\end{abstract}

Keywords: Vanadium complexes, Tris(1-pyrazolyl)methanesulfonate; Tripodal ligands; Cyclic voltammetry.

\section{Introduction}

Tris(1-pyrazolyl)methanesulfonates, $\mathrm{SO}_{3} \mathrm{Cpz}_{3}{ }^{-}$(pz = pyrazolyl), with three $\mathrm{N}-$ deprotonated pyrazole rings bound to a carbon atom, hydrolytically stable and soluble in polar protic solvents, constitute a rather promising class of tripodal Ndonor ligands in modern coordination chemistry [1]. However, vanadium complexes containing these ligands have not been reported so far.

We have been able [2] to synthesise the first tris(1-pyrazolyl)methanesulfonate vanadium(IV) complex, $\left[\mathrm{VCl}_{3}\left(\mathrm{SO}_{3} \mathrm{Cpz}_{3}\right)\right]$ ( $\mathrm{pz}=$ pyrazolyl), derived from vanadium(III) chloride in the presence of lithium tris(1pyrazolyl)methanesulfonate, which was completely characterized by IR and EPR spectroscopy, FAB-MS spectrometry and elemental analysis. Its electrochemical behaviour is described as follows.

\footnotetext{
* Corresponding author. E-mail address: tsilva@dem.isel.ipl.pt
} 


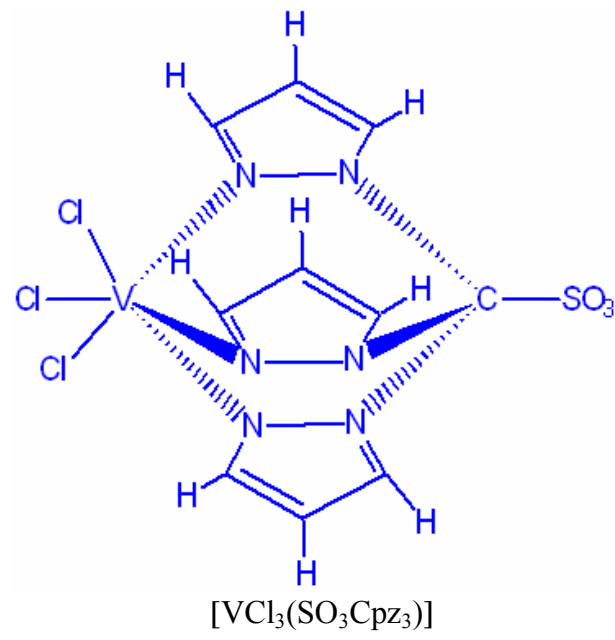

\section{Results and discussion}

The redox properties of the vanadium complex $\left[\mathrm{VCl}_{3}\left(\mathrm{SO}_{3} \mathrm{Cpz}_{3}\right)\right](\mathrm{pz}=$ pyrazolyl) were studied by cyclic voltammetry $(\mathrm{CV})$ in a two-compartment three-electrode cell, at a Pt disc working electrode $(\phi=500 \mu \mathrm{m})$ and by controlled potential electrolysis (CPE), in a three-compartment three-electrode cell, at a Pt gauze working electrode, by using an EG\&G PAR 273A potentiostat/galvanostat. Both techniques were carried out in an inert atmosphere $\left(\mathrm{N}_{2}\right)$, at room temperature, in a non-aqueous aprotic medium, $0.2 \mathrm{M}\left[\mathrm{Bu}_{4} \mathrm{~N}\right]\left[\mathrm{BF}_{4}\right] / \mathrm{CH}_{2} \mathrm{Cl}_{2}$. The redox potentials are quoted relative to the $\mathrm{SCE}$ by using as internal reference the ferrocene/ferricinium couple $\left(\mathrm{E}_{1 / 2}{ }^{\text {ox }}=0.525 \mathrm{~V} v\right.$ s. SCE in $\left.\mathrm{CH}_{2} \mathrm{Cl}_{2}\right)$.

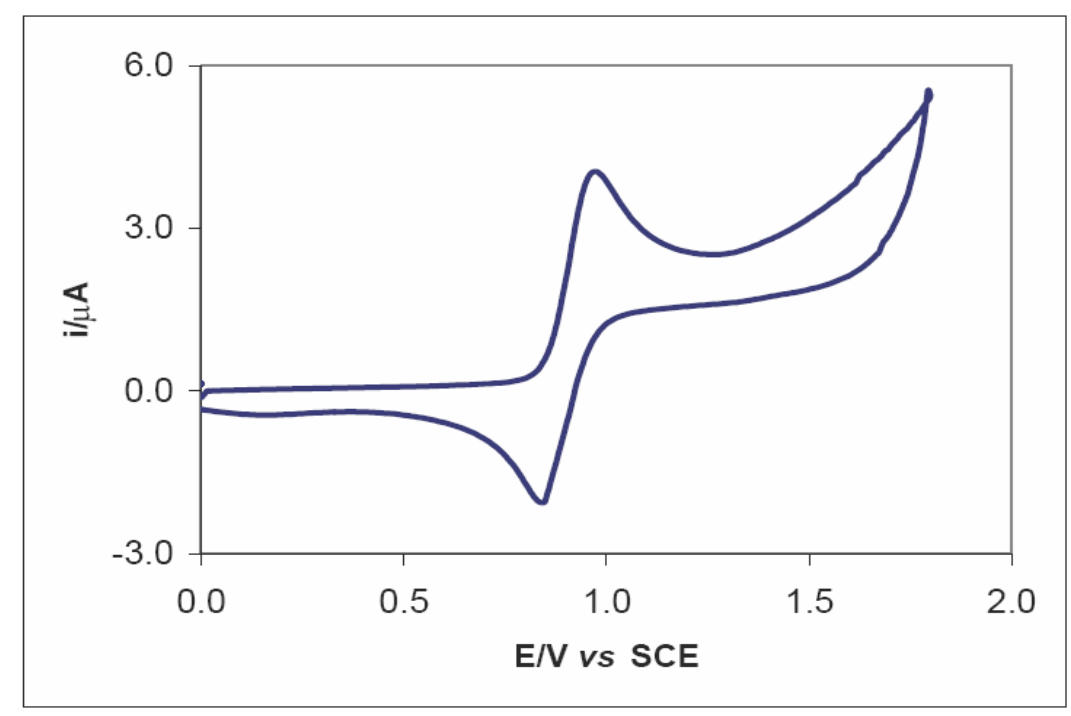

Figure 1. Cyclic voltammogram of the complex $\left[\mathrm{VCl}_{3}\left(\mathrm{SO}_{3} \mathrm{Cpz}_{3}\right)\right]$ at a $\mathrm{Pt}$ disc electrode, in a $0.2 \mathrm{M}\left[\mathrm{Bu}_{4} \mathrm{~N}\right]\left[\mathrm{BF}_{4}\right] / \mathrm{CH}_{2} \mathrm{Cl}_{2}$ solution $\left(\mathrm{v}=0.2 \mathrm{Vs}^{-1}\right)$. 
This complex exhibits only one single-electron (CPE) fully reversible $\left(\mathrm{ip}_{\mathrm{a}} / \mathrm{ip}_{\mathrm{c}}=1\right.$; $\Delta \mathrm{E} \cong 70 \mathrm{mV}$ ) oxidation wave at $\mathrm{E}_{1 / 2}{ }^{\text {ox }}=1.14 \mathrm{~V} v s$. SCE corresponding to the oxidation of $\mathrm{V}(\mathrm{IV})$ to $\mathrm{V}(\mathrm{V})$ (Fig. 1), whereas lithium tris(1-pyrazolyl)methanesulfonate is electrochemically inert in the potential range from $-2.0 \mathrm{~V}$ to $+2.0 \mathrm{~V}$, at the above experimental conditions.

The $\mathrm{V}^{\mathrm{IV} / \mathrm{V}}$ redox potential of our complex lies within the range of those reported for other $\mathrm{V}^{\mathrm{IV}}$ complexes with related tripodal ligands, namely the hydrotris(1pyrazolyl)borate oxovanadium(IV) complexes [3] indicated in Table 1, which also undergoes a single-electron oxidation, although not fully reversible at the studied cyclic voltammetric time scale.

Table 1. Oxidation potential of vanadium(IV) complexes in $\mathrm{CH}_{2} \mathrm{Cl}_{2}$.

\begin{tabular}{lc}
\hline \multicolumn{1}{c}{ Complex } & $\mathrm{E}^{\mathbf{o}}(\mathrm{V} v s . \mathrm{SCE})$ \\
\hline$\left[\mathrm{VCl}_{3}\left(\mathrm{SO}_{3} \mathrm{Cpz}_{3}\right)\right]$ & 1.14 \\
\hline$\left[\mathrm{VO}\left(\mathrm{HBpz}_{3}\right)(\mathrm{acac})\right]$ & 1.21 \\
{$\left[\mathrm{VO}\left\{\mathrm{HB}\left(3,5-\mathrm{Me}_{2} \mathrm{pz}\right)_{3}\right\}(\mathrm{acac})\right]$} & 1.07 \\
{$[\mathrm{VO}(\mathrm{Cl})(\mathrm{HBpz})(\mathrm{DMF})]$} & 1.33 \\
{$\left[\mathrm{VO}(\mathrm{Cl})\left\{\mathrm{HB}\left(3,5-\mathrm{Me}_{2} \mathrm{pz}\right)_{3}\right\}(\mathrm{DMF})\right]$} & 1.21 \\
\hline
\end{tabular}

$($ acac $=$ acetilacetonate $; D M F=$ dimethylformamide $)$

\section{Final comments}

We are now extending the synthetic and electrochemical study to derivatives of $\left[\mathrm{VCl}_{3}\left(\mathrm{SO}_{3} \mathrm{Cpz}_{3}\right)\right]$ and to other metal tris(pyrazolyl)methanesulfonate complexes in order to attempt establishing redox potential-structure and -composition relationships.

\section{Acknowledgements}

This work has been partially supported by the IPL/41/2003 project, the POCTI (FEDER funded) program and the Fundação para a Ciência e Tecnologia (FCT), and the AQUACHEM Project RTN n ${ }^{\circ}$ MRTN-CT-2003-503864, Portugal.

\section{References}

1. J.A. McCleverty, T.J. Meyer, Comprehensive Coordination Chemistry II: From Biology to Nanotechnology (2003) Vol. 1, Elsevier, p. 195.

2. T.F.S. Silva, L.M.D.R.S. Martins, A.A. Espada and A.J.L. Pombeiro, $6^{\text {th }}$ Conference on Inorganic Chemistry, Madeira (2005) PP 22, p. 72.

3. M. Mohan, S.M. Holmes, R.J. Butcher, J.P. Jasinski and C.J. Carrano, Inorg. Chem. 31 (1992) 2029. 